\title{
The fate of bleached corals: patterns and dynamics of algal recruitment
}

\author{
Guillermo Diaz-Pulido ${ }^{1,2, *}$ Laurence J. McCook ${ }^{2}$ \\ ${ }^{1}$ Department of Tropical Plant Sciences, James Cook University, Townsville, Queensland 4811, Australia \\ ${ }^{2}$ Australian Institute of Marine Science \& CRC: Reef Research, Townsville, Queensland 4811, Australia
}

\begin{abstract}
The mass bleaching of corals that occurred on the Great Barrier Reef (GBR), Australia, in early 1998 was one of the most severe on record. There is surprisingly little known about the fate of bleached corals, which may either regain their zooxanthellae and recover, or may die, in which case they generally become overgrown by algae. The nature and dynamics of this algal overgrowth and its effects on the corals are not well understood. In this study we describe the composition and time-course of algal recruitment on bleached corals, and the possible roles of that recruitment on the fate of the corals, at 2 inshore reefs of the GBR. Massive Porites spp. corals were selected with different degrees of bleaching, and the cover of live coral tissue, and relative abundance and composition of algal recruitment were followed in small plots over $2.5 \mathrm{yr}$. The bleaching disturbance precipitated a major shift in abundance of corals and algae. All dead corals were colonised by a diverse community of epilithic and endolithic algae, the nature and composition of which was variable and related to the stage of the succession, the severity of bleaching and reef location. Quantitative data on species composition of colonising algae are given, and are apparently the first such data. The epilithic algal assemblage was initially dominated by diatoms and blue-green algae, but rapidly shifted to an assemblage dominated by upright and branched filamentous algae (e.g. Polysiphonia spp., Hincksia mitchelliae, Sphacelaria spp.) and, on 1 reef, fleshy macroalgae (e.g. Asparagopsis taxiformis, Sargassum spp.). Endolithic algal assemblages were largely dominated by the green algae Ostreobium spp. and cyanobacteria. Algal colonisation on clay settlement plates was distinctly different from that on dead coral skeleton. Algal colonisation was not the initial cause of coral tissue mortality, although it may have contributed to the failure of corals to recover after bleaching. The results thus emphasise the role of coral disturbances and substratum availability in controlling abundance of coral reef benthic algae, in contrast to 'bottom-up' and 'top-down' views that assume changes in algal abundance are the major cause of changes in coral abundance. The considerable variability in the outcome of bleaching damage and algal colonisation demonstrates the potential for major and variable effects on the recovery of coral populations, with implications for the future reef status.
\end{abstract}

KEY WORDS: Coral bleaching · Algal turfs · Algal colonisation · Succession · Phase shifts $\cdot$ Coralalgal competition $\cdot$ Macroalgae $\cdot$ Disturbances

\section{INTRODUCTION}

Coral bleaching is an important cause of coral mortality, potentially resulting in large-scale declines in coral populations, which amount to reef degradation (Glynn 1993, Hoegh-Guldberg 1999). Several mass-

*E-mail: guillermo.diaz@jcu.edu.au bleaching events have been recorded on coral reefs around the world during the last $20 \mathrm{yr}$, and there is concern that such events may be increasing in frequency (Brown 1997, Hoegh-Guldberg 1999). The most recent mass bleaching, in early 1998, was one of the strongest bleaching events on record for the Great Barrier Reef, Australia (Berkelmans \& Oliver 1999). Research on coral bleaching has largely focussed on the climatological and physiological causes of bleach-

(ㄷ) Inter-Research $2002 \cdot$ www.int-res.com 
ing, behaviour of zooxanthellae and, importantly, the recovery of zooxanthellae (Brown 1997, HoeghGuldberg 1999). However, there has been little work addressing the fate of bleached corals that fail to recover their zooxanthellae (Brown 1997).

Bleached coral tissue may either regain its zooxanthellae and recover, or may die, in which case it is generally rapidly colonised by benthic algae. Large-scale mass-bleaching events may result in massive algal overgrowth of the newly available substratum provided by the dead coral skeleton (Wellington \& Victor 1985, Glynn 1990). These changes may thus amount to a partial or extensive phase shift, in which abundant benthic algae replace abundant corals, potentially amounting to or contributing to long-term reef degradation just as severe as that caused by diseases, eutrophication or over-fishing (Birkeland 1987, Glynn 1993, Aronson \& Precht 1997, McCook 1999, McClanahan et al. 2001). Despite the importance of such changes, very little is known about the dynamics of algal colonisation of bleached corals.

The composition and type of algal colonisation may be important to the consequences of coral bleaching both in terms of the severity of disturbance and the potential for future reef recovery. The severity of the disturbance may be influenced by the effects of the colonising algae on the ability of corals to recover from bleaching. The composition and successional trajectory of the colonising algae may also influence the ability of coral populations to re-establish on algal dominated substratum, either through recolonisation by surviving corals or new recruitment. The outcome of the competitive interaction between corals and benthic algae may depend on the species of coral and alga involved and the mechanism mediating the interaction (McCook et al. 2001a), with consequences for the processes of reef phase shifts and recovery from disturbances (McCook 1999). For example, Bak et al. (1977) reported that filamentous turfing algae delay the regeneration of coral tissue after mechanical damage. In contrast, Meesters \& Bak (1993) found that filamentous algae did not affect coral recovery, and in one instance, canopy-forming Sargassum spp. beds were found to protect corals from bleaching damage (Jompa \& McCook 1998).

This study explores the patterns of algal colonisation of bleached corals, and the potential interactions with the corals. The study addressed 4 specific questions: (1) What are the patterns and variations in coral tissue recovery or mortality, subsequent to different degrees of bleaching damage? (2) What are the nature, composition and trajectory through time of algal colonisation of bleached corals? (3) Does such colonisation depend on the severity or degree of bleaching? (4) Does the algal colonisation influence the fate of the bleached corals and the chances of coral recovery?

To address these questions we examined the abundance and species composition of algal recruitment and cover of live coral tissue on massive corals (Porites spp.) with different degrees of bleaching over a period of $2.5 \mathrm{yr}$.

\section{MATERIALS AND METHODS}

Study sites. The study was carried out at Orpheus Island and Pandora Reef, which are located $30 \mathrm{~km}$ apart on the inshore central section of the Great Barrier Reef, GBR (Fig. 1). By late February and early March 1998, coral reefs of this area had suffered severe and extensive coral bleaching associated with raised seawater temperatures (Baird \& Marshall 1998, Sweatman et al. 1998, Berkelmans \& Oliver 1999, authors' pers. obs. for this site). The study site at Orpheus Island was on the reef crest on the sheltered, western side of the

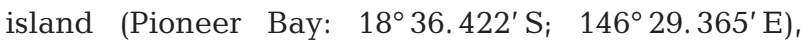
where the fringing reef between 1 and $7 \mathrm{~m}$ depth is dominated by large massive colonies of Porites spp.

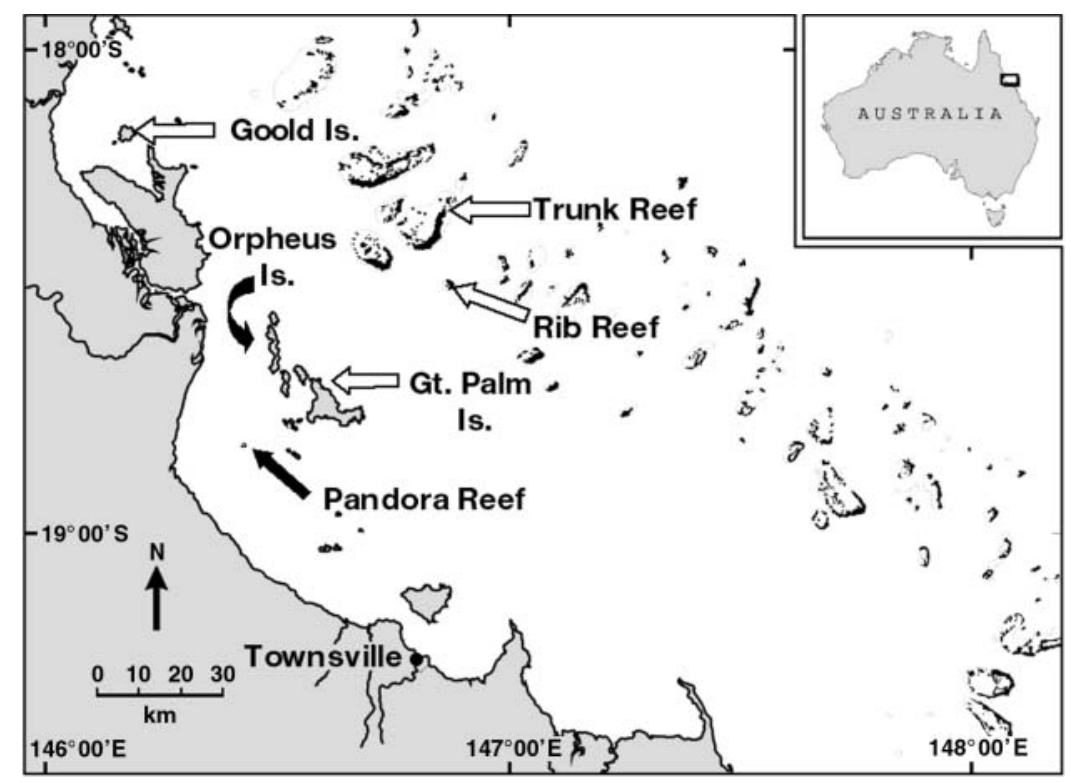

Fig. 1. Central section of the Great Barrier Reef, Australia, showing study sites (black arrows). Qualitative observations were made at a range of inshore and mid-shelf sites over the period of this study (open arrows) 
(P. australiensis, P. lobata and P. lutea). Pandora Reef is a shingle covered bank reef. The study site was on the southern, windward side of the reef $\left(18^{\circ} 49.009^{\prime} \mathrm{S}\right.$; $\left.146^{\circ} 26.035^{\prime} \mathrm{E}\right)$ at 3 to $6 \mathrm{~m}$ depth. The reef here is also dominated by large colonies of massive Porites spp., and stands of dead branched acroporids and fleshy macroalgae (see also Done 1982, Done \& Potts 1992).

Sampling design and methods. Coral survival and mortality and algal colonisation were monitored using a combination of detailed, quantitative small-scale measurements over a range of conditions, and qualitative observations at larger scales (Fig. 1). To determine whether the trajectory of algal colonisation onto bleached corals depended on the severity of bleaching, we monitored benthic algal recruitment in 3 different 'bleaching categories' over $2.5 \mathrm{yr}$. We defined the 3 categories to represent different levels in a gradient of bleaching damage to corals: 'healthy' (initially having $100 \%$ cover of unbleached, live coral tissue), 'bleached' (initially with $100 \%$ cover of recently bleached, live coral tissue with no dead tissue and no algal colonisation; see Fig. 7) and 'severely bleached' (i.e. coral tissue/skeleton areas partially overgrown by a thin algal turf layer, but clearly identifiable as bleached during this event). To explore the extent to which algal recruitment was location-specific, bleaching treatments were replicated on 2 reefs (Orpheus \& Pandora). To investigate the extent to which the patterns of algal colonisation were specific to bleached corals, 8 ceramic settlement plates $(11 \times 11 \mathrm{~cm})$ were fixed to the substratum in the study area at Orpheus Island for comparison with coral substrates.

The bleached and severely bleached corals were found subtidally between 2 and $5 \mathrm{~m}$ depth. However, at Orpheus Island, bleaching damage at these depths was so severe that no healthy corals could be found, so control (healthy) corals were chosen at deeper depth (6 m). Thus, these comparisons may be confounded by the depth difference. Massive Porites spp. colonies were chosen because they are particularly common on the inshore reefs and are the most important reef-building corals on the inshore GBR (Hopley 1982).

For each of the bleaching categories, 8 plots $(10 \times 10 \mathrm{~cm})$ were marked on horizontal surfaces on the top of massive colonies of Porites spp., and the fate of the bleached coral in these plots was monitored by measuring percent cover of live coral tissue and benthic algae (at both species and functional group levels) using both direct observations and photographs. Where sufficient suitable coral colonies were available, we selected 1 plot per colony, using colonies with fairly homogeneous bleaching damage (although most colonies had less bleaching on their sides than their tops). The cover of live corals, benthic algal groups (algal turfs, fleshy macroalgae and crustose coralline algae, CCA) and species of fleshy macroalgae was esti- mated by projecting the photographic slides onto a grid of 100 quadrats. Photographic sampling at Orpheus Island was carried out on 11 dates at intervals of 1 to 4 mo between April 1998 and August 2000. At Pandora Reef, restricted access in bad weather meant that photographic sampling was only possible on 7 dates in the same period.

The species composition and abundance of settled algal turfs were monitored by scraping areas of approximately $1 \mathrm{~cm}^{2}$ to a depth of 1 to $2 \mathrm{~mm}$ (therefore including endolithic taxa) adjacent to each coral plot. Sampling dates included autumn (April and May 1998 and 1999 and March 2000) and winter (July 1998 and 1999). Algal turf samples were decalcified with $10 \%$ $\mathrm{HCl}$ and stained with a solution of aniline blue (Price \& Scott 1992), then spread homogeneously over $2 \times 2 \mathrm{~cm}$ on a microscope slide, and scanned with a compound microscope to record all algae taxa present. The relative abundances of algal taxa were estimated by determining the percent cover in 5 microscopic fields at $100 \times$. Representative specimens of the most abundant taxa are lodged at the JCT herbarium (James Cook University, Townsville). Endolithic taxa were separated based on direct observations of growth habit and published records (Le Campion-Alsumard et al. 1995).

Data analyses included 1-way ANOVA and Tukey's HSD (using Systat ${ }^{\mathrm{TM}}$ 8.0) to compare the means in cover of corals and algal groups amongst treatments (fixed factor) at each date. Patterns of species abundances and composition in relation to bleaching treatments, locations, date and height of the overall algal turf canopy were analysed using principal-components and redundancy analyses (using CANOCO 4: ter Braack \& Šmilauer 1998) and time-series plots for more abundant taxa (details not presented). Bleaching treatment, location, date and algal turf height were treated as 'environmental variables' in the redundancy analysis (ter Braack \& Šmilauer 1998). The cover data for coral and algal groups was arcsine-transformed, and data for algal turf species was log-transformed before statistical analyses to homogenise variances.

\section{RESULTS}

\section{Overall patterns}

The sequence of events following the coral bleaching is summarised in Fig. 2. In general, coral tissue that recovered zooxanthellae within 4 to 6 mo after the bleaching survived, whereas tissue that did not recover zooxanthellae within this period died and was rapidly colonised by thin algal turfs. Algal colonisation occurred between 1 to 6 mo after the bleaching, and no further replacement of corals by algae could be attrib- 


\section{The fate of bleached corals}

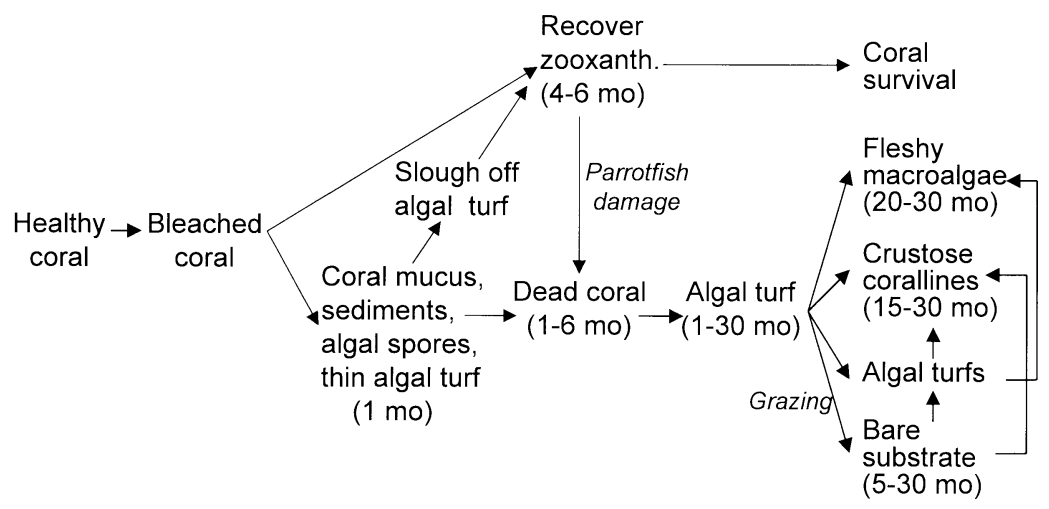

Fig. 2. Porites spp. Diagram summarising events following coral bleaching over a period of $30 \mathrm{mo}$

uted to bleaching damage after approximately 7 mo (September 1998). At the beginning of the bleaching event (February to April 1998), many corals produced an abundant layer of mucus. This mucus accumulated together with a fine film of sediment and provided substrata for settlement and growth of algal propagules, even when overlying bleached live coral polyps. In some cases, this thin mucus-sediment-algal layer ( $<2 \mathrm{~mm}$ thick) was sloughed off, often followed by recovery of the corals. In other cases, the algae were apparently able to attach to the coral skeleton. Algal turfs dominated algal colonisation for more than $2.5 \mathrm{yr}$, although fleshy macroalgae and crustose coralline algae (Figs. 3 \& 4) overgrew some turfs during later stages of the succession. Subsequent grazing on algal turfs and corals by parrotfishes created bare substratum that was again colonised by algal turfs (Fig. 2). Qualitative observations at a range of reefs in the central GBR (Fig. 1) suggest widespread patterns of change similar to those documented in detail here, although coral mortality at Orpheus Island and Pandora Reef was apparently particularly severe.

\section{Time-course of coral and algal cover in relation to degree of bleaching}

The trajectories of live coral tissue cover and benthic algal cover indicated that coral death was always followed by rapid colonisation with algal turfs composed of microalgae and filamentous algae (Figs. $3 \& 4$ ). In bleached and severely bleached plots, the cover of live coral tissue declined over the first 6 to $7 \mathrm{mo}$, and was replaced by algal turfs. All healthy corals (i.e. plots chosen as initially having $100 \%$ cover of unbleached, live coral tissue) remained healthy through the study period at both locations. Algal cover on healthy coral tissue was never more than $5 \%$, and was always much lower than that on bleached and severely bleached corals (Figs. $3 \& 4$; maximum $\mathrm{p}<0.037$, Tukey's test).

There were some differences in trajectories between bleached and severely bleached plots, but these were largely quantitative: the more bleaching the more coral death, and consequently the more algal turf overgrowth. Bleached coral plots exhibited higher live coral tissue cover (maximum p $<0.04$, Tukey's test) and lower algal colonisation (maximum $\mathrm{p}<0.03$, Tukey's test) than the severely bleached corals during the first 6 mo (note that in general severely bleached plots initially had some algal colonisation, whereas bleached plots had $100 \%$ cover of bleached but living coral tissue). However, from 7 mo (September 1998) until the end of the study (August 2000), although patterns of coral and algal cover remained similar, the differences between bleached and severely bleached plots were generally not significant ( $p>0.05$, Tukey's test). In the bleached treatment, cover of live coral tissue decreased to less than $30 \%$ after 7 to 9 mo and then remained relatively constant (Figs. 3 \& 4). Algal turfs reached 50 to $60 \%$ cover in the first 3 mo and remained high over $2.5 \mathrm{yr}$, with relatively minor subsequent changes. Photographs show that some of the decline in coral cover in bleached plots at Orpheus Island between 5 and 7 mo after bleaching was due to parrotfish grazing on recently recovered bleached corals $(12 \%$ decline in coral cover, with related increases in bare substratum and then algal turfs). Successional trajectories varied considerably within bleached treatments, both between plots and between dates (Figs. $3 \& 4$ ).

In the severely bleached plots (which were chosen as initially having partial colonisation by algal turfs), the cover of live coral declined from $30 \%$ to $<5 \%$ in $1 \mathrm{mo}$ at Orpheus Island and from $60 \%$ to $12 \%$ in 3 mo at Pandora Reef (Figs. $3 \& 4$ ). The percentage of cover of live coral subsequently remained low. As dead coral was always colonised by algal turfs, turfs increased to $95 \%$ and $70 \%$ cover after 3 mo at Orpheus Island and Pandora Reef respectively. Fleshy macroalgal and CCA cover remained low throughout the study at Orpheus Island. However, at Pandora Reef, fleshy macroalgae, including Sargassum spp., Asparagopsis taxiformis, Lobophora variegata and Dictyosphaeria versluysii, became slightly more abundant in the later stages of the study. There was some temporal and spatial variation in successional trajectories within severely bleached plots, although less than in bleached plots (Figs. 3 \& 4). 


\section{Trajectory of algal species composition during succession}

The species composition of the algae recruiting to the bleached and severely bleached corals varied over the time-course of the succession and between plots (within categories and dates). Early stages of the algal succession of severely bleached corals (ca. $<3$ mo after the bleaching) were characterised by mixed thin algal turfs composed of up to 20 taxa from 5 algal phyla (Table 1). Pennate diatoms and coccoid and filamen-
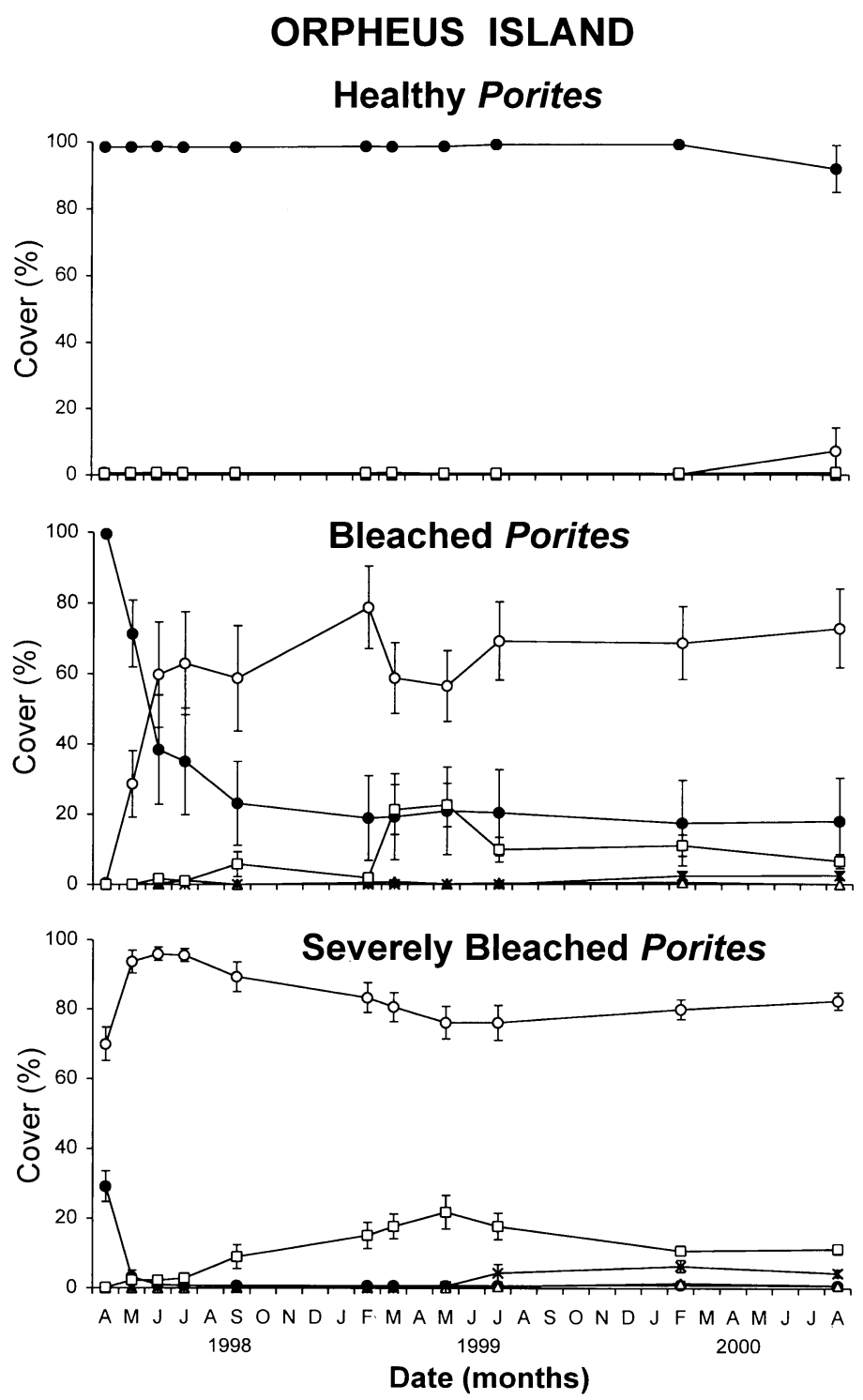

Fig. 3. Porites spp. Trajectories of coral and benthic algal cover (mean $\pm \mathrm{SE}, \mathrm{n}=8$ ) through time in 3 bleaching categories at Orpheus Island. All areas had $100 \%$ live coral cover before the bleaching event. $(\bullet)$ corali $_{(0)}$ algal turfs; $(\Delta)$ fleshy macroalgae; $(x)$ crustose coralline algae; $(\square)$ bare substratum tous blue-green algae (Plectonema terebrans and Spirulina subsalsa) dominated the early stages with up to $50 \%$ of relative abundance. The brown alga Hincksia mitchelliae and the green endolithic algae Ostreobium spp. were also abundant during the early stages of the succession. Mid-to-late stages of the succession were dominated by a diverse epilithic and endolithic assemblage of blue-green algae and turfing algae of more complex morphologies, including red (Anotrichium tenue, Polysiphonia scopulorum), brown (H. mitchelliae, Sphacelaria tribuloides and S. rigidula) and green (Ostreobium spp.) algae. Algal species richness increased slightly early during the succession but was highly variable during later stages (Table 1).

Redundancy analyses clarified several patterns in the time-course of the turf assemblage. For example, several pioneer species occurred almost exclusively at the beginning of the succession (e.g. Spirulina subsalsa; top of Fig. 5a). Similarly, several taxa appeared predominantly at later successional stages (Hyella spp., Polysiphonia upolensis, Taenioma nanum and Entocladia robusta: bottom of Fig. 5a \& Table 1). Juvenile (Table 1) and adult (Table 2) stages of fleshy macroalgae such as Asparagopsis taxiformis, Sargassum spp., Lobophora variegata, Dictyota spp. and Dictyosphaeria versluysii, were mainly recorded in later stages of the algal succession.

Although the structure of the algal assemblage on severely bleached corals 3 mo after the bleaching was very similar to that observed after $24 \mathrm{mo}$, there were considerable changes during the intervening period (Fig. 6). However, in both bleached and severely bleached plots, algal community structure apparently 'stabilised' 15 mo (May 1999) after the bleaching event, with only minor changes apparent in the last 10 mo.

\section{Species composition in relation to extent of bleaching and substratum type}

The species composition of colonising algae differed between bleached and severely bleached plots (Fig. 6), although this variation was relatively minor compared to temporal changes, as indicated by the close overlap of the vectors for the 2 categories in the redundancy analysis (Fig. 5b). The differences were most pronounced during early stages of succession and at Orpheus Island, where species composition on severely bleached plots during early stages was apparently in a 'more developed' successional stage than that in the bleached plots. These differences were largely due to a higher abundance of coccoid cyanobacteria in the bleached plots, and a higher abundance of Herposiphonia secunda and Ostreobium spp. in severely bleached plots (Table 1). The algal composition in the 
Table 1. Mean relative \% abundance (see 'Materials and methods'; $\mathrm{n}=8$ ) of turf algae that colonised each of the bleaching categories (S: severely bleached Porites spp.; B: bleached Porites spp.) and clay plates (C) at 2 locations in April, May and August 1998 and March 1999 and 2000

\begin{tabular}{|c|c|c|c|c|c|c|c|c|c|c|c|c|c|c|c|}
\hline \multirow{3}{*}{ Algal taxon } & \multirow{2}{*}{ Apr 1998} & \multirow{2}{*}{\multicolumn{3}{|c|}{$\overline{\text { May } 1998}$}} & \multicolumn{6}{|c|}{ Drpheus } & \multirow{3}{*}{$\begin{array}{l}\text { Aug } 1998 \\
\text { S }\end{array}$} & \multicolumn{2}{|c|}{ _ Pandora } & \multirow{2}{*}{\multicolumn{2}{|c|}{ Mar 2000}} \\
\hline & & & & & \multicolumn{3}{|c|}{ Mar 1999} & \multicolumn{3}{|c|}{ Mar 2000} & & \multicolumn{2}{|c|}{8 Mar 1999} & & \\
\hline & $\mathrm{S}$ & B & $\mathrm{S}$ & $\mathrm{C}$ & B & $\mathrm{S}$ & $\mathrm{C}$ & B & $\mathrm{S}$ & $\mathrm{C}$ & & B & $\mathrm{S}$ & B & $\mathrm{S}$ \\
\hline Pennate diatoms & 17.1 & 2.0 & 1.5 & 16.2 & 2.6 & 2.0 & 9.1 & 4.5 & $5 \quad 3.1$ & 4.8 & 9.5 & 2.9 & 3.1 & 2.7 & 3.6 \\
\hline Blue green algae & & & & & & & & & & & & & & & \\
\hline Calothrix crustacea & $<0.1$ & 0.7 & 2.8 & 0.7 & 1.2 & 5.6 & 2.2 & 1.1 & $1 \quad 1.7$ & $7 \quad 3.2$ & 0.2 & 0.5 & 1.6 & 0.1 & 0.1 \\
\hline Coccogonales spp. & 3.6 & 12.0 & 1.9 & 20.2 & 3.2 & 2.0 & 15.0 & 1.7 & $\begin{array}{l}7 \\
7.2\end{array}$ & 5.3 & 2.8 & 2.7 & 1.4 & 0.6 & 0.4 \\
\hline Hyella spp. & & & & & & 1.4 & & 0.1 & $1 \quad 0.7$ & & & & & & \\
\hline Mastigocoleus testarum & & & & & 0.1 & 3.7 & $7 \quad 0.1$ & 0.7 & $7 \quad 2.7$ & $7<0.1$ & & 5.0 & 4.7 & 2.4 & 2.7 \\
\hline Oscillatoriales spp. & 5.2 & 2.2 & 5.7 & 3.1 & 4.7 & 5.4 & 5.2 & 2.3 & 32.2 & 6.9 & 5.9 & 17.4 & 12.5 & 2.1 & 5.9 \\
\hline Plectonema terebrans & 14.7 & 37.8 & 15.4 & 2.6 & 1.6 & 3.5 & 3.2 & 12.1 & 10.9 & 4.6 & 3.2 & 2.7 & 1.3 & 2.7 & 5.8 \\
\hline Spirulina subsalsa & 9.5 & 3.7 & 0.3 & $<0.1$ & $<0.1$ & & 0.1 & 0.3 & & & 5.0 & 0.1 & 0.4 & & 0.1 \\
\hline Undetermined sp. & & & & & & & & & & & 0.3 & & & & \\
\hline Red algae & & & & & & & & & & & & & & & \\
\hline Acrochaetium spp. & & & 0.0 & & & & & & & $<0.1$ & & & & 0.1 & \\
\hline Amphiroa sp. & & & & & & & & & & & & & & $<0.1$ & \\
\hline Anotrichium tenue & 1.0 & 2.7 & 7.0 & 0.5 & 0.7 & 0.9 & 0.1 & 9.9 & $9 \quad 9.3$ & 8.5 & & & 0.6 & $<0.1$ & $<0.1$ \\
\hline Asparagopsis taxiformis & & & & & & & & & & & & & & 11.6 & 0.6 \\
\hline Centroceras apiculatum & & & & $<0.1$ & & & & & & & & & & & \\
\hline Centroceras clavulatum & 4.3 & 3.0 & 4.9 & 10.1 & 0.1 & 0.1 & 0.1 & 1.0 & 2.9 & $\quad 1.3$ & 18.3 & & 14.2 & $<0.1$ & 0.9 \\
\hline Ceramium codii & $<0.1$ & 0.4 & $4 \quad 0.1$ & 1.2 & & 0.1 & 0.7 & & 0.1 & & 0.1 & & & $<0.1$ & $<0.1$ \\
\hline Ceramium flaccidum & 0.7 & 1.6 & 0.3 & 2.3 & & & & & & & 7.1 & 2.8 & 5.3 & 1.1 & 2.0 \\
\hline Ceramium punctiforme & & & 0.2 & 1.0 & & & & & & & & & & & \\
\hline Chondria sp. & & & & & $<0.1$ & 0.9 & & & & & & & & & \\
\hline Corallophila huysmansii & 3.3 & & 2.8 & 1.8 & 1.8 & 0.3 & 3.2 & 4.5 & $5 \quad 5.1$ & 0.8 & & & & & \\
\hline Crustose corallines & & 6.0 & 0.7 & $<0.1$ & $<0.1$ & 0.6 & 1.0 & & $<0.1$ & 1.3 & 0.3 & & & & \\
\hline Gelidiella pannosa & 7.1 & $<0.1$ & 1.9 & & 4.3 & 13.9 & 0.6 & 1.1 & $1<0.1$ & 8.1 & & 0.7 & 1.5 & 0.6 & 1.9 \\
\hline Gelidiopsis intricata & & & & & & & & $<0.1$ & 10.8 & & & & & & 0.2 \\
\hline Griffithsia heteromorpha & 0.1 & & 1.6 & 0.1 & & & & & & 0.5 & & & & & \\
\hline Herposiphonia secunda $f$. sec. & 0.2 & $<0.1$ & 5.4 & 2.7 & 1.0 & 5.0 & 12.0 & 8.3 & 36.0 & 8.0 & & & $<0.1$ & & 0.7 \\
\hline Hypnea spinella & & & $<0.1$ & & & & & & & & & & & & 0.2 \\
\hline Jania adhaerens & & & $<0.1$ & & & $<0.1$ & & & & & 1.8 & & $<0.1$ & 1.2 & 2.3 \\
\hline Laurencia sp. & & $<0.1$ & 0.1 & 0.1 & & & & $<0.1$ & $1<0.1$ & 2.5 & $<0.1$ & & & & $<0.1$ \\
\hline Polysiphonia scopulorum & 0.1 & 1.2 & 10.6 & 1.3 & 15.2 & 15.1 & 22.3 & 17.3 & 7.2 & 18.2 & 5.7 & 32.5 & 17.4 & 36.0 & 20.0 \\
\hline Polysiphonia upolensis & & & & & & & & 6.2 & 2.4 & 2.5 & & & & & 3.6 \\
\hline Pterocladia caerulescens & & & & & & & & & & & & & & 0.3 & \\
\hline Spermothamnion sp. & & & 0.4 & $<0.1$ & 0.7 & 0.1 & & 0.5 & $5 \quad 1.6$ & & 2.4 & 3.7 & 8.7 & 8.8 & 7.7 \\
\hline Spyridia filamentosa & & & & & & & & & 0.2 & & & & & & 0.7 \\
\hline Taenioma nanum & & & & & 2.5 & 2.4 & 4.4 & 1.6 & 0.7 & $7 \quad 3.6$ & & & 1.5 & 6.6 & 2.0 \\
\hline Undetermined sp. & & & $<0.1$ & & & & & & & & & & & & \\
\hline Brown algae & & & & & & & & & & & & & & & \\
\hline Dictyota sp. & & & & & & & & & 0.9 & & & & & 0.2 & \\
\hline Hincksia mitchelliae & 7.8 & 8.5 & $5 \quad 4.3$ & 15.4 & 21.9 & 1.3 & $3 \quad 0.3$ & 10.5 & $5 \quad 7.7$ & $>0.1$ & 32.2 & 0.9 & 1.6 & 0.2 & 2.8 \\
\hline Lobophora variegata & & & & & & & & & & 0.6 & & & & & \\
\hline $\begin{array}{l}\text { Sphacelaria spp. } \\
\quad \text { (tribuloides \& rigidula) }\end{array}$ & 5.9 & 3.0 & 015.0 & 2.2 & 13.0 & 16.2 & 13.2 & 6.1 & 10.3 & 17.1 & 3.2 & 19.6 & 11.8 & 13.3 & 26.2 \\
\hline Green algae & & & & & & & & & & & & & & & \\
\hline Acetabularia (Polyphysa) sp. & & & & & & & & & & $<0.1$ & & & & & $<0.1$ \\
\hline Blastophysa rhizopus & & & & & & & & & & 0.8 & & & & & \\
\hline Cladophora dalmatica & 6.7 & 1.5 & $5 \quad 1.5$ & 3.7 & 0.8 & 0.2 & 2.6 & 0.2 & $2 \quad 0.4$ & 0.7 & $<0.1$ & 1.0 & 3.4 & 1.0 & 2.8 \\
\hline Derbesia marina & & & & & & & & 0.3 & & & & & & & \\
\hline Derbesia fastigiata & & 2.8 & $8 \quad 4.9$ & 0.4 & & & & & & & & & & 0.6 & 0.4 \\
\hline Enteromorpha linza & 5.8 & 10.1 & 11.1 & 14.4 & 0.5 & 0.7 & $7 \quad 0.6$ & 0.2 & $2 \quad 0.4$ & 0.3 & & 0.1 & $<0.1$ & 0.1 & 0.1 \\
\hline Entocladia robusta & & & & & & & & 1.9 & $9 \quad 1.6$ & 0.1 & & & & & \\
\hline $\begin{array}{l}\text { Ostreobium spp. } \\
\text { Udotea sp. }\end{array}$ & 7.0 & 0.8 & $8 \quad 9.7$ & & 24.2 & 19.8 & & 7.8 & $\begin{array}{l}18.1 \\
<0.1\end{array}$ & 0.5 & 2.0 & 7.4 & 9.0 & 7.6 & 6.5 \\
\hline Species richness & 20 & 21 & 29 & 24 & 22 & 24 & 20 & 26 & 29 & 27 & 19 & 16 & 21 & 26 & 30 \\
\hline Total abundance & 100 & 100 & 100 & 100 & 1001 & 100 & 100 & 100 & 100 & 100 & 100 & 1001 & 100 & 1001 & 100 \\
\hline
\end{tabular}



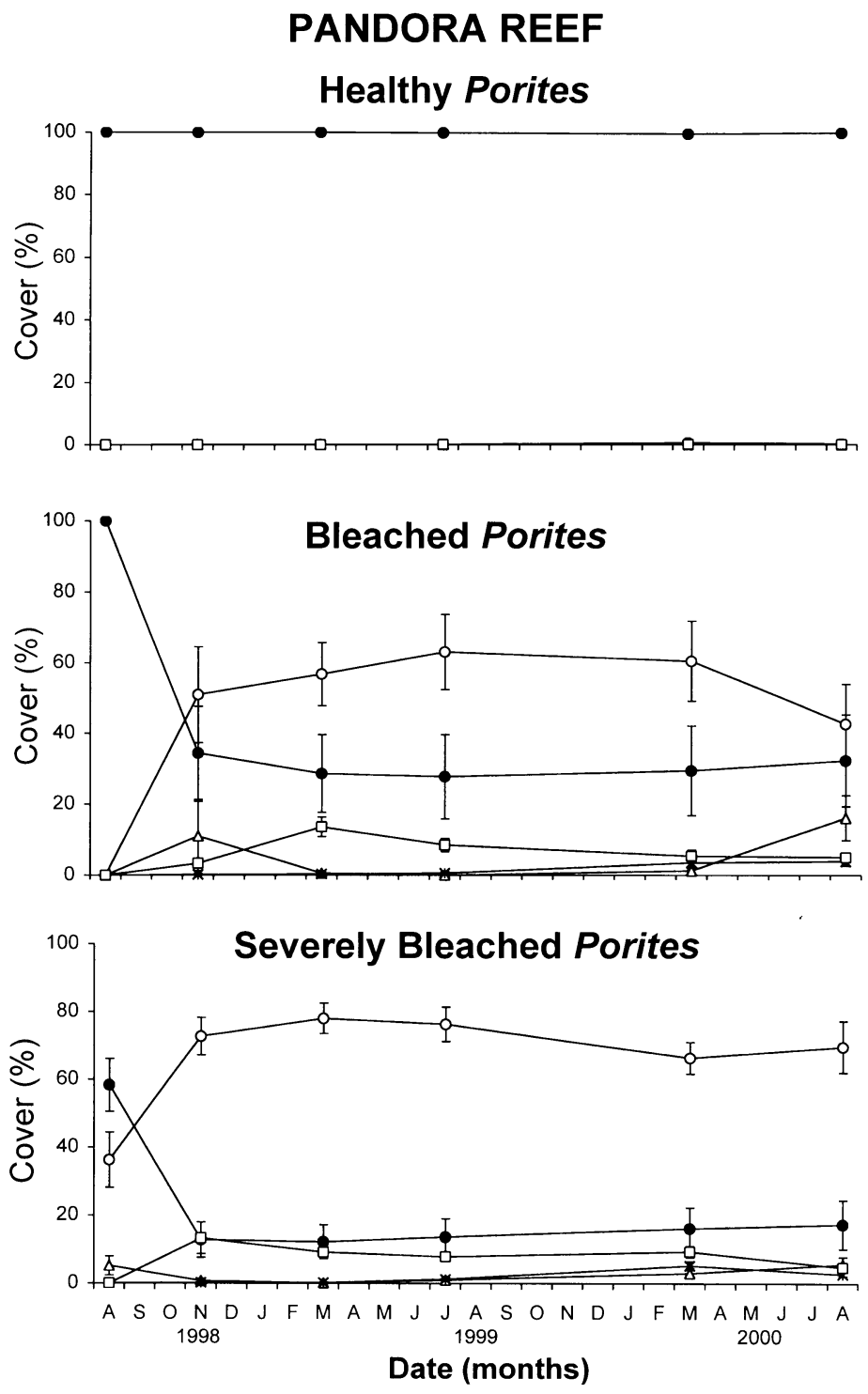

Fig. 4. Porites spp. Trajectories of coral and benthic algal cover (mean $\pm \mathrm{SE}, \mathrm{n}=8$ ) through time in 3 bleaching conditions at Pandora Reef. All areas had $100 \%$ live coral cover before the bleaching event. $(\bullet)$ coral $_{\text {; }}(0)$ algal turfs; $(\Delta)$ fleshy macroalgae; $(x)$ crustose coralline algae; $(\square)$ bare substratum. Note that although standard error bars are small, standard deviations would be approximately 3 times larger, indicating moderate variation among plots

2 categories converged after about 1.5 to 2 yr (Fig. 6). On Pandora Reef the variation in species composition during early stages was apparently not related to the extent of bleaching.

The redundancy and principal components analyses (PCA) indicate distinct differences in algal composition between substratum types (bleached and severely bleached coral substrates versus clay plates: Figs. 5 \& 6). The vector representing clay plates is opposite to the coral substratum vectors in the redundancy analysis (Fig. 5b), and in the PCA all clay plate samples are located on the far left of the plot (Fig. 6). Characteristic species of coral substrates include the endolithic algae Ostreobium spp. and Mastigocoleus testarum (on right of Fig. 5a). To determine whether the differences in species composition between substrates were due only to the endolithic forms, we repeated the redundancy analysis excluding the endolithic taxa. This analysis (details not included here) showed that the differences persist, due to higher abundance of early successional taxa (pennate diatoms and coccoid cyanobacteria) on the clay plates (Table 1).

\section{Differences between locations and the outcome of algal colonisation}

There were marked differences in algal composition between the 2 locations, indicated by the length and opposite directions of vectors in the redundancy analysis (Fig. 5b) and by the distinct separation of locations in the PCA (Fig. 6). In particular, the red algae Spermothamnion sp. and juvenile stages of Asparagopsis taxiformis were found almost exclusively on Pandora Reef (Fig. 5), whereas the red filamentous algae Corallophila huysmansii and Anotrichium tenue occurred mainly on Orpheus Island. The locations also differed in the presence at Pandora Reef of a distinct assemblage of fleshy macroalgae dominated by adult $A$. taxiformis, juvenile Sargassum spp. (<2 to $10 \mathrm{~cm}$ height) and Dictyota spp. (Table 2).

\section{Algal colonisation and recovery of bleached corals: apparent competition}

Recovery rates for Porites spp. were very low in this study. Two and a half years after the bleaching event, only 20 to $30 \%$ of the bleached and 1 to $15 \%$ of the severely bleached coral areas remained alive at Orpheus Island and Pandora Reef respectively (Figs. 3 \& 4). Bleaching was clearly an important source of tissue mortality for massive Porites spp. at these sites.

Although not directly tested, there is some indication that algal colonisation influenced the recovery of the bleached corals, but that this effect was variable (Fig. 7). Plots where algal turfs were present initially (severely bleached treatment) had consistently higher coral tissue mortality (i.e. lower cover) than plots that initially had no algae present (bleached treatment). Bleached coral tissue that was not colonised by algal turfs uniformly regained zooxanthellae and recovered. In contrast, few bleached and severely bleached coral plots which were overgrown by turf algae were able to 
a. Species composition

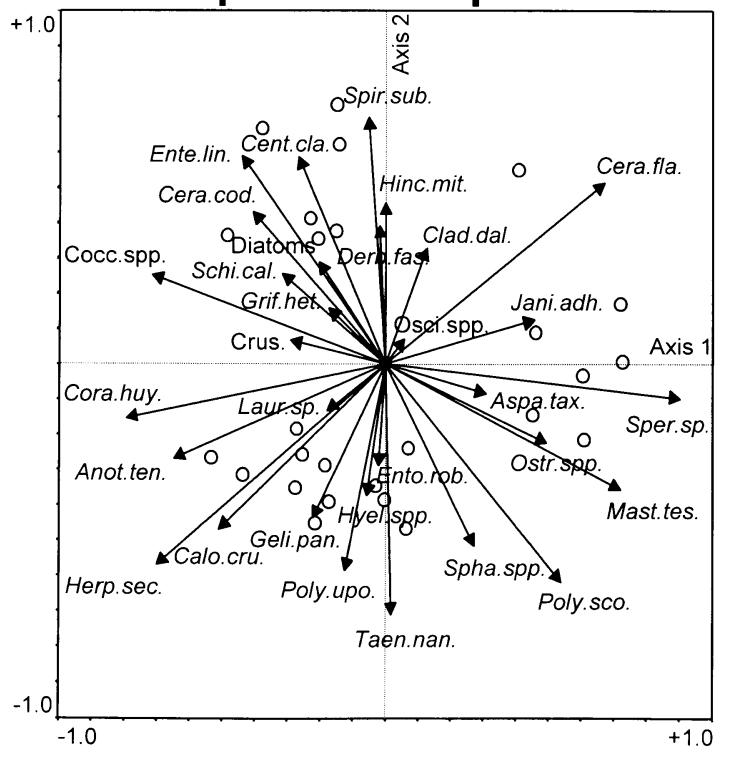

b. Environmental variables

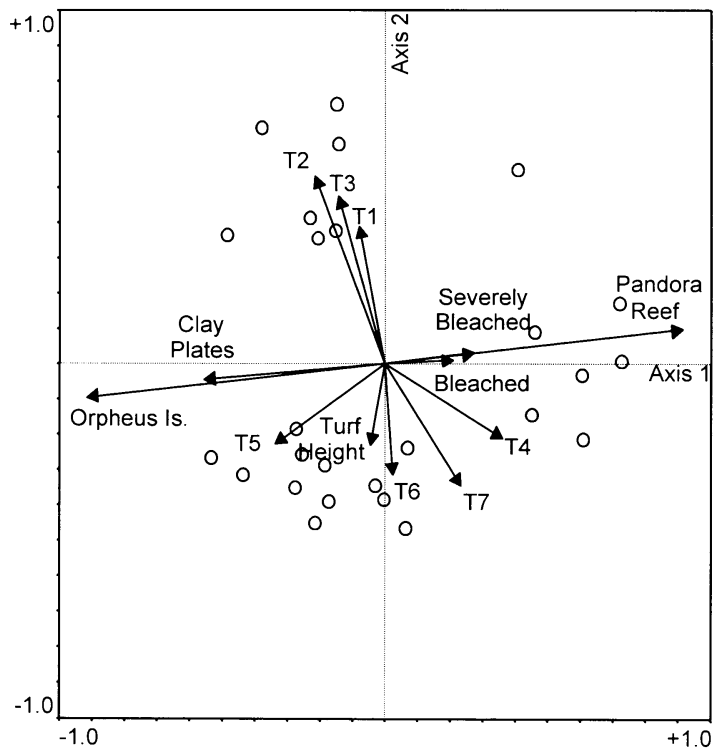

Fig. 5. Ordination plots based on the redundancy analysis (RDA) of abundance data for 48 species of turfing algae; circles represent averages of 8 samples. (a) RDA plotting species (arrows) and sample averages (circles). Full taxa names are given in Table 1. Rare species with $<1 \%$ total abundance were excluded from the plot. Arrow lengths are proportional to the proportion of variance of the species explained by the 2 axes. (b) The same RDA showing environmental variables (arrows) and sample averages (circles), where the lengths of arrows are proportional to the strength of association between variable and ordination. T1: April 1998 (2 mo after bleaching); T2: May 1998 (3 mo); T3: July 1998 (5 mo); T4: March 1999 (13 mo); T5: May 1999 (15 mo); T6: July 1999 (17 mo); T7: March 2000 (25 mo). Axes 1 and 2 of RDA explain $43.5 \%$ of variance in the species abundance and $61.8 \%$ of variance in the correlations of species with respect to environmental variables. Eigenvalues of Axes 1, 2 and 3 (latter not displayed) are 0.240, 0.194 and 0.097 respectively; sum of all canonical eigenvalues is 0.703 . p-value of Monte Carlo test of all canonical axes is 0.005

exclude the epilithic algae and recover (Figs. $3 \& 4$ ), presumably due to competitive inhibition by the algae (Fig. 7a). However, photographic sequences showed that even after coral tissue death and algal turf colonisation, the outcome was not uniform. In some plots, areas of dead coral tissue that had been colonised by algae did recover, as surrounding healthy coral tissue overgrew the algal turfs (Fig. 7b). This recovery apparently occurred by a competitive process.

\section{DISCUSSION}

This study documents several significant aspects of coral bleaching events, including: (1) bleaching as the cause of a major shift in abundance of coral and benthic algae; (2) a detailed description of the patterns and composition of algal colonisation of bleached corals; (3) variability in algal colonisation, in particular amongst degrees of bleaching, locations, successional stages and substratum types; (4) potential contri- butions of algal colonisation to coral tissue mortality. The following subsections discuss each of these points in turn and suggests that, overall, interactions between benthic algae and corals may be critical to understanding the consequences of coral bleaching events.

Table 2. Mean absolute \% cover of fleshy macroalgae that colonised Porites spp. corals at 2 locations over time (data were obtained photographing $10 \times 10 \mathrm{~cm}$ plots; $\mathrm{n}=16$ ). Since there were no significant differences in \% cover of fleshy macroalgae between bleached and severely bleached coral categories, the percentages of both bleaching categories were averaged

\begin{tabular}{|c|c|c|c|c|c|c|c|c|}
\hline \multirow[t]{3}{*}{ Algal taxon } & \multicolumn{4}{|c|}{ - Orpheus } & \multicolumn{4}{|c|}{ - Pandora } \\
\hline & Jul & Mar & Feb & Aug & Aug & Mar & Mar & Aug \\
\hline & 1998 & 1999 & 2000 & 2000 & 1998 & 1999 & 2000 & 2000 \\
\hline Asparagopsis taxiformis & & & & & & & & 5.4 \\
\hline Sargassum spp. & & & $<0.1$ & & & & 1.1 & 3.5 \\
\hline Lobophora variegata & & 0.5 & 0.3 & 0.5 & 0.3 & 0.3 & 0.6 & 1.5 \\
\hline Laurencia spp. & 0.5 & & 0.2 & 0.1 & 0.9 & & & \\
\hline Dictyota spp. & & & & & 1.4 & 0.1 & 0.1 & \\
\hline Dictyosphaeria versluysii & & 0.1 & & & & & & 0.3 \\
\hline Acetabularia (Polyphysa) sp. & & & & & & & 0.3 & 0.1 \\
\hline Chlorodesmis fastigiata & & & 0.2 & & & & & \\
\hline Galaxaura rugosa & & & 0.2 & & & & & \\
\hline Padina sp. & 0.1 & & $<0.1$ & & & & & \\
\hline Pterocladia caerulescens & & & & & & & 0.1 & \\
\hline Valonia sp. & & & & & & & & 0.1 \\
\hline
\end{tabular}




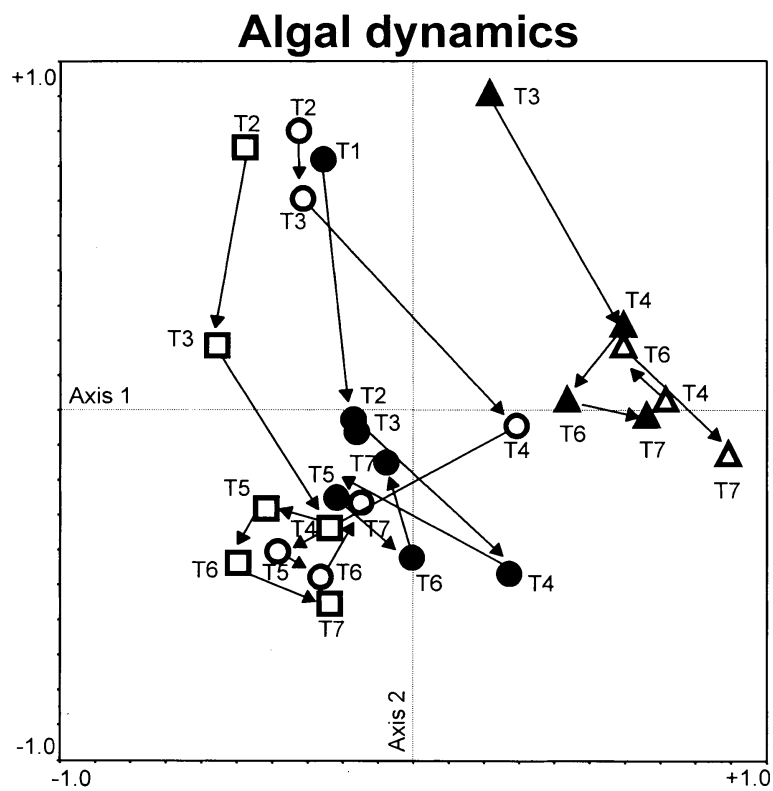

Fig. 6. Ordination plot based on principal components analysis (PCA) of algal turf species abundance data, showing temporal dynamics for different substrata and locations. Arrows show trajectories through time of algal colonisation. T1 to T7: dates as in Fig. 5; symbols represent sample averages. Orpheus Island: $(O)$ bleached corals, $(\bullet)$ severely bleached corals, $(\square)$ clay plates; Pandora Reef: $(\Delta)$ bleached corals, $(\boldsymbol{\Lambda})$ severely bleached corals. First and second axes of the diagram account for 26 and $23 \%$ of variance in species data, and

third axis (not shown) accounts for $11 \%$ of the variance

\section{Bleaching disturbance as cause of a major shift in abundance of corals and benthic algae}

The 1998 mass bleaching of corals resulted in a significant shift in abundance of corals and benthic algae. Coral mortality was widespread, both regionally and globally (Baird \& Marshall 1998, Berkelmans \& Oliver 1999, Wilkinson 2000, McClanahan et al. 2001, authors' pers. obs.). Coral mortality at our sites was high (Figs. 3 \& 4, qualitative observations), indicating that this bleaching event was a major disturbance, as massive Porites spp. are considered highly resistant to bleaching and other injuries (Sweatman et al. 1998, van Woesik 1998, Berkelmans \& Oliver 1999, Marshall \& Baird 2000). Importantly, in the present study, all corals that died from bleaching were colonised by algal turfs, with higher algal overgrowth on more severely bleached corals but no colonisation on healthy corals. Algal overgrowth of corals was clearly a consequence of the bleaching event. Although caution is required in applying results from relatively small quadrats to larger scale processes, our larger-scale, qualitative observations on these and other reefs in the area suggest that the results are representative of general patterns on bleached corals. Rapid colonisation by algae after coral disturbances is a general phenomenon, documented following extreme low tides (Fishelson 1973), crown of thorn starfish predation (Price 1975), mechanical injuries (Meesters \& Bak 1993) and bleaching events (Wellington \& Victor 1985, Glynn 1993, Hoegh-Guldberg 1999).

The replacement of coral by algae in this study depended on the prior death or debilitation of the corals by bleaching. This shows how disturbance to corals and substratum availability may be critical mediators of shifts in dominance from coral- to algae-dominated systems. Much attention has focussed on the relative importance of eutrophication (bottom-up) and overfishing of herbivores (top-down) as direct causes of macroalgal blooms on coral reefs (e.g. Hughes et al. 1999, Lapointe 1999, etc). In both of these scenarios, decreases in coral abundance are assumed to be caused by increases in algal abundance (due to increased algal competitiveness). However, disturbances such as bleaching may result in similar relative changes in abundance of coral and algae but with reversed causality: the decline in coral abundance is the cause of increased algal abundance. Such distinctions may have significant implications, in particular if human impacts limit the recovery of reefs from natural disturbances, rather than or as well as directly causing coral mortality (Glynn 1993, Aronson \& Precht 1997, McClanahan \& Muthiga 1998, McCook 1999, McCook et al. 2001b).

\section{Successional trends in recruitment}

Coral mortality due to bleaching generally results in algal colonisation, yet the details of such colonisation have not been investigated, although reef algal succession has been documented in other circumstances (Price 1975, Carpenter 1990, McClanahan 1997). Algal colonisation of bleached corals in this study followed a typical successional pattern, with dominance of diatoms and blue-green algae in early stages followed by taxa with more complex morphologies during later stages (Table 1). The shifts in composition towards a more mature epilithic turf community, dominated by upright and branched filamentous algae, is consistent with studies of algal succession in tropical (Carpenter 1990, Hixon \& Brostoff 1996) and temperate (McCook \& Chapman 1993, 1997, Lopez-Rodriguez \& Perez-Cirera 1998) areas. The changes in composition after 15 mo may reflect normal community dynamics, such as seasonality and herbivore-grazing effects, as well as continuing successional changes.

The species composition of later stages in this study is similar to that of other coral reef epilithic turf com- 


\section{a. Algae overgrew coral}
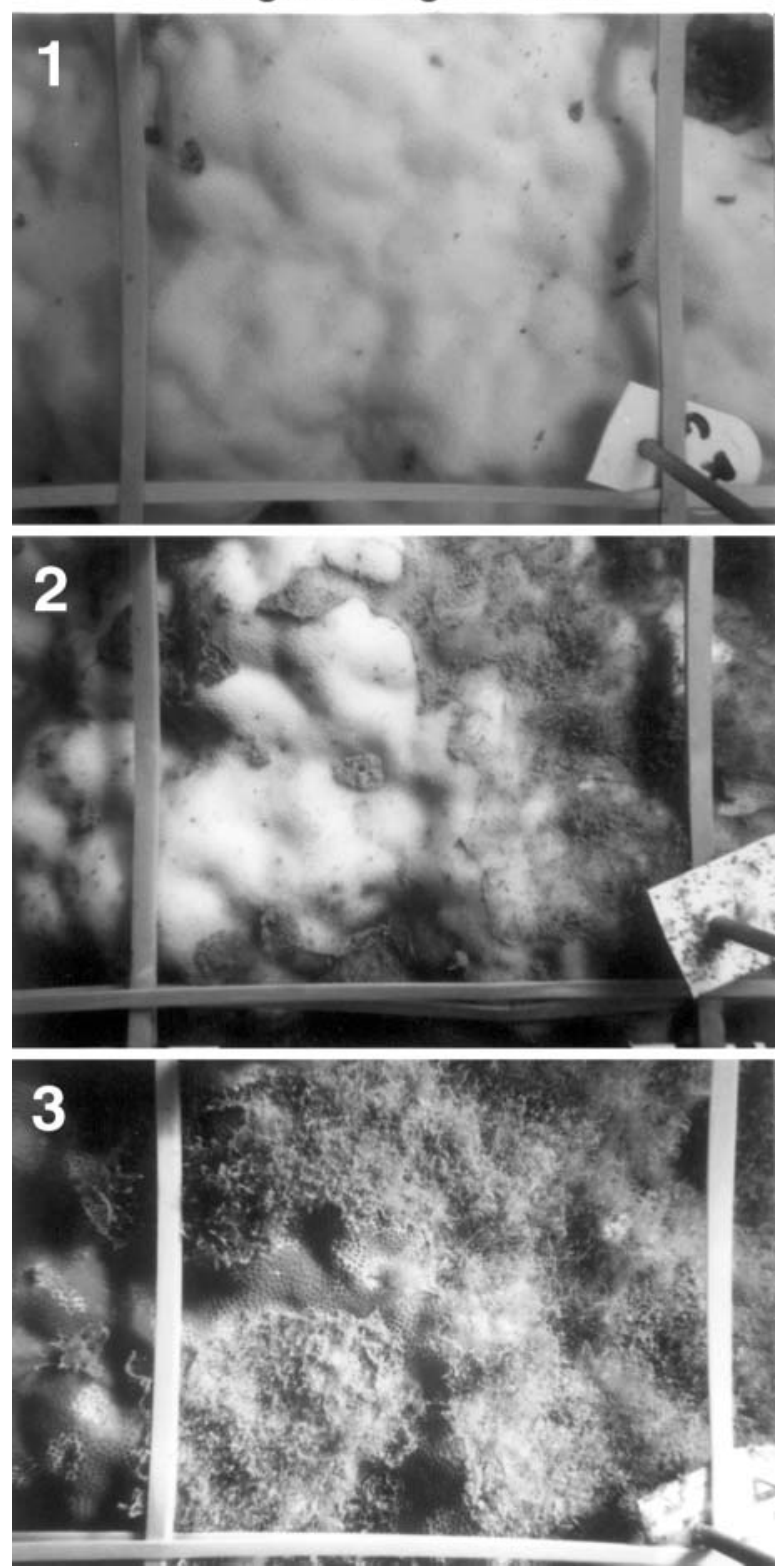

b. Coral overgrew algae
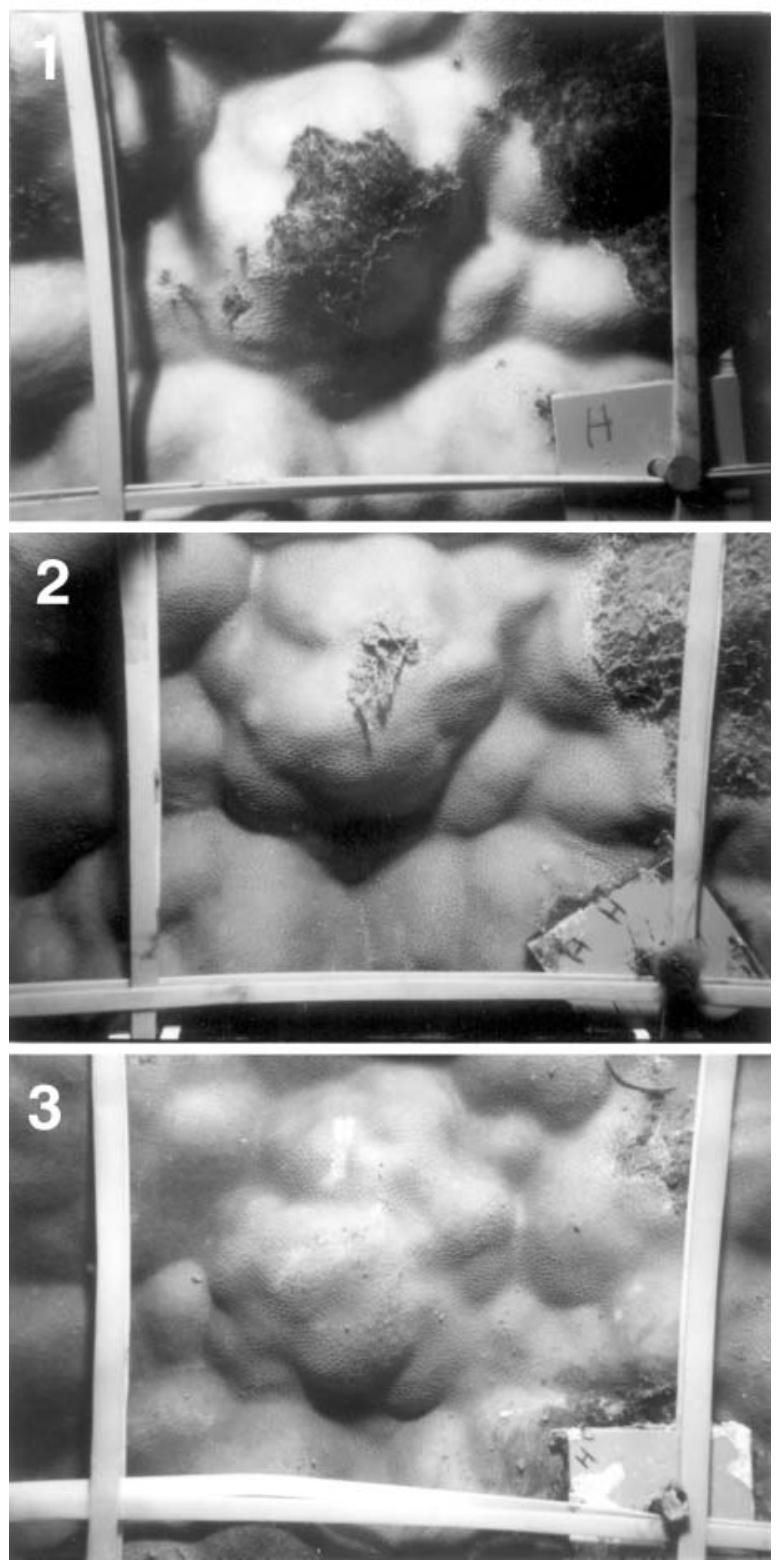

Fig. 7. Porites spp. Photographic sequences for 2 plots $(10 \times 10 \mathrm{~cm})$ after the bleaching event in early 1998 , illustrating the variability in outcomes of coral recovery. In (a), the coral did not recover from algal overgrowth (plot from Orpheus Island), remaining dominated by algal turfs until August 2000. (a1) April 1998, (a2) May 1998, (a3) July 1998. In contrast, in (b) the coral recovered successfully from the algal turf colonisation (plot from Pandora Reef). (b1) November 1998, (b2) July 1999, (b3) August 2000. Both corals started with $100 \%$ bleached coral cover and were subsequently partially overgrown by algal turfs

munities in this area (Scott \& Russ 1987, McCook, Price \& Diaz-Pulido unpubl. data) and elsewhere (Belk \& Belk 1975, Carpenter 1990, Steneck \& Dethier 1994, Hixon \& Brostoff 1996), with abundant Sphacelaria spp., Polysiphonia spp., Hincksia spp. and species of Oscillatoriales. In contrast to Hixon \& Brostoff (1996), who found that early successional forms were quickly replaced by encrusting algae on Hawaiian coral reefs, encrusting algae were scarce in our study, although also increasing during the course of the succession. Fleshy macroalgae occurred predominantly in the final stages of this succession (both in small plots and in larger-scale, qualitative observations), reflecting their slower colonisation rates, and could be expected to play a greater role in dynamics over longer time periods. 
The endolithic algal assemblage that developed on bleached Porites spp. in our study was very similar to those found on other tropical reefs (Le CampionAlsumard et al. 1995, Hixon \& Brostoff 1996, Le Bris et al. 1998). In Le Campion-Alsumard's et al. study of endolithic microbial colonisation of blocks cut from dead massive Porites labata, they observed that Ostreobium spp. dominated later in the succession (second year) whereas, in our study, Ostreobium spp. appeared soon after the bleaching event. Since Ostreobium spp. populations are known to live in healthy corals (Le Campion-Alsumard et al. 1995), these differences probably reflect delays in colonising newly cut coral blocks, compared to recently bleached corals where Ostreobium spp. may already have been present.

\section{Variability in algal colonisation and composition between bleaching categories, substratum types and locations}

Algal colonisation of bleached corals was not uniform, but varied considerably both in overall patterns and in species composition. Although much of this variability could be accounted for in terms of differences between dates, bleaching categories, locations, and substratum types, there was also considerable variation even among plots under similar conditions. Importantly, much of this variability persisted through time, with differences remaining 25 mo after the bleaching event.

The severity of bleaching damage to corals apparently affected both the trajectory and outcome of algal colonisation. Corals with more severe bleaching suffered more extensive tissue mortality and consequent algal overgrowth. Although these differences persisted to the end of the study, they were not statistically significant at the later stages. However, this may simply reflect the high variability in bleached plots, which results in decreased experimental power (i.e. possible Type II error). Within the areas overgrown by algae, differences in species composition of the algae between bleaching categories were also greatest early in the study (Fig. 6). More severely bleached plots supported a more mature assemblage during early and intermediate stages, but the differences decreased as succession progressed in the less severely bleached plots. Presumably, the early differences simply reflected slower coral tissue mortality in less severely bleached plots, and consequent delay in initiation of the succession.

Substratum types differed markedly in the composition of algal assemblages, and these differences persisted to the end of the study period. Dead coral plots supported more later successional taxa, and endolithic forms were absent from clay substrates (Table 1). Hixon \& Brostoff (1996) also found that natural sub- strates supported a later successional stage than artificial substrates. It is likely that endolithic algae could not penetrate the clay plates, although substratum chemistry and texture may also be important (Harlin \& Lindbergh 1977).

Reef location accounted for more variation in algal composition than any of the other factors considered here. These differences were marked in both turfing taxa and larger fleshy macroalgae, and persisted over 2.5 yr. In particular, fleshy macroalgae were more abundant and different in composition at Pandora Reef than at Orpheus Island, where they were essentially absent (Table 2). The extent of these differences between 2 inshore reefs is intriguing. Factors that might contribute to the differences in larger, fleshy macroalgae include: (1) lower levels of herbivory at Pandora Reef compared to reefs located more offshore (Scott \& Russ 1987, Klumpp \& McKinnon 1992); (2) a potentially higher availability of propagules due to the proximity of dense populations of fleshy macroalgae at Pandora Reef; (3) different physical and chemical conditions, for example, nutrients and sediment inputs could be higher at Pandora Reef due to its more inshore location and the potential for resuspension of muddy bottom sediments (Russ \& McCook 1999). However, differences in turf composition are difficult to explain in terms of between-reef differences in herbivory or proximity of propagule supply, and may simply reflect different species pools on the 2 reefs due to physical or chemical conditions or stochastic variations.

The extent of variability in the amount and composition of algal recruitment on bleached corals and the diversity of contributing factors provide strong evidence that the consequences of bleaching mortality should not be assumed to be uniform, but may vary considerably depending on the severity and timing of the disturbance, the location, and substratum. This is especially important because different patterns of algal colonisation may have different effects on the potential for later recovery of coral populations. For example, different fleshy macroalgae (e.g. Asparagopsis taxiformis, Sargassum spp. or Lobophora variegata) may have very different effects on coral recruitment or regrowth compared to algal turfs, because of different mechanisms involved in the interaction (McCook et al. 2001a). Previous work in this area found algal turfs to have little effect on growth of massive Porites spp. (McCook 2001), whereas fleshy macroalgae may strongly inhibit coral recovery by smothering, abrasion, shading, etc. (Jompa \& McCook 2002). Colonisation by abundant crustose coralline algae might even facilitate coral recruitment (Heyward \& Negri 1999). Fleshy macroalgae, once established, may persist and dominate for long periods, markedly changing habitat structure (Hatcher 1984 for Asparagopsis taxiformis). 


\section{Potential interactions between benthic algae and coral bleaching}

Although it is clear that algae were not the initial cause of coral tissue mortality (see first subsection of 'Discussion'), it is possible that algal colonisation contributed to the failure of corals to recover from the disturbances (fourth subsection of 'Results'). It is difficult to determine the extent of this contribution, since unequivocal demonstration of a contribution by algae would require direct experimental removal of the colonising algae (Underwood 1986, McCook et al. 2001a), technically very difficult to achieve without inflicting confounding damage to the coral. Certainly, the poor recovery of severely bleached corals is presumably largely intrinsic to the tissue stress caused by the bleaching damage, potentially compounded by tissue shrinkage or the sequestering of metabolic resources between areas within a colony (effectively sacrificing further stressed tissue areas). However, it is possible that processes of the disturbance-induced stress and algal competition synergise, with more stressed corals being more vulnerable to algal overgrowth and algal overgrowth enhancing the stress. Even where bleaching stress is not sufficiently severe to kill the coral tissue, the stressed corals may have a reduced ability to clean themselves or to avoid algal competitors. Production of a mucus layer apparently serves as a defensive mechanism against sediment accumulation and epibiotic colonisation (Lang \& Chornesky 1990), and it is likely that nutritional deficiency caused by the loss of zooxanthellae (Szmant \& Gassman 1990, Glynn 1993, Meesters \& Bak 1993) reduces the ability of the corals to defend themselves in this manner. Meesters \& Bak (1993) have previously shown that bleached corals are more easily overgrown by algae than healthy corals when injuries are inflicted to the tissue.

The consequences of algal colonisation were not uniform. Although in most cases algal overgrowth of dead coral tissue was persistent, in some instances the coral was apparently able to regain lost ground, apparently by competitive overgrowth (Fig. 7). Algal colonisation has previously been suggested to delay and inhibit recovery after coral disturbances and pre-empt space, thus inhibiting future coral settlement and recruitment (Bak et al. 1977, Birkeland 1977, Hughes 1996, Connell et al. 1997). In contrast, there are also examples of competitive superiority of corals over algal turfs, both on inshore reefs in this region of the GBR (McCook 2001) and in other regions (Fishelson 1973, Meesters \& Bak 1993, Littler \& Littler 1997, van Woesik 1998). Algae may not prevent coral recovery after small-scale damage (Meesters \& Bak 1993), although the ability of corals to heal injuries that have been overgrown by benthic algae decreases as the size of the lesion increases (van Woesik 1998). In our study, the low proportional recovery after overgrowth by algal turfs probably reflects the combined extent and severity of bleaching damage.

Overall, benthic algae have the potential to interact significantly with various stages of the bleaching process, with potentially very different consequences. The presence of an abundant macroalgal canopy has been shown to reduce damage to corals at the time of bleaching, apparently by shading (Jompa \& McCook 1998). Algal colonisation subsequent to bleaching may increase the impact of bleaching stress to corals (see previous paragraph). Finally, long-term patterns of algal colonisation and succession on dead coral substrates may influence the ability of coral populations to recover, either by new recruitment or by regeneration of surviving tissue (see third subsection of 'Discussion' and Fig. 7b; see also Glynn 1993). The marked contrast between the apparently beneficial effects of shading and the competitive effects, in combination with the potential variability within each of these effects, suggests that these overall interactions may have considerable consequences for the outcome of coral bleaching events.

\section{Recurrent future bleaching events and the impor- tance of benthic algal interactions and dynamics}

Recent predictions suggest that coral bleaching events will become more frequent and even more severe (Brown 1997, Hoegh-Guldberg 1999). In such a scenario, it is inevitable that coral reefs will display increased and increasingly variable cover of benthic algae with considerable potential to influence future reef recovery. As emphasised above, differences in the type and abundance of algae that overgrow bleached corals, both initially and in the long-term, are likely to be critical to reef dynamics and trajectories. There has been debate about the consequences of the predicted increases in bleaching damage, with suggestions that coral populations may adapt or may recover by means of reseeding from more resistant populations (Glynn 1993). However, the success of such scenarios depends on the ability of remnant corals to vegetatively overgrow substrata occupied by algae, or the ability of coral larvae to successfully settle and recruit once they arrive at a damaged reef. The substratum on that reef is likely to be dominated by various forms of benthic algae. Understanding, predicting and managing the consequences of future bleaching events will depend on a better understanding, not only of coral physiology, climatology, and coral recruitment dynamics, but also of algal recruitment dynamics and coral-algal interactions after disturbances. 
Acknowledgements. This study was funded by the Great Barrier Reef Marine Park Authority, The CRC: Reef Research Centre, James Cook University, the Australian Institute of Marine Science, and by a fellowship from the Instituto Colombiano para el Desarrollo de la Ciencia y la Tecnología - 'COLCIENCIAS'. We thank J. Jompa, C. P. Arango, G. Arango, A. Chinn, D. Egli, F. Olivier, E. Potter and A. Walli for field assistance, J. Jompa, R. Steneck, M. and D. Littler, J. Oliver and R. Berkelmans for valuable discussions, B. McArdle for statistical advice, I. Price for taxonomic help, and H. Sweatman, D. Barnes, J. Lough, J. Skeat and 2 reviewers for their comments on the manuscript. This is AIMS Contribution No. 1084.

\section{LITERATURE CITED}

Aronson RB, Precht WF (1997) Stasis, biological disturbance, and community structure of a Holocene coral reef. Paleobiology 23:326-346

Baird AH, Marshall PA (1998) Mass bleaching of corals on the Great Barrier Reef. Coral Reefs 17:376

Bak RPM, Brouns JJWM, Heys FML (1977) Regeneration and aspects of spatial competition in the scleractinian corals Agaricia agaricites and Montastrea annularis. In: Taylor DL (ed) Proceedings of the 3rd International Coral Reef Symposium, Vol. 1. Rosenstiel School of Marine and Atmospheric Science, University of Miami, p 143-148

Belk MS, Belk D (1975) An observation of algal colonization on Acropora aspera killed by Acanthaster planci. Hydrobiologia 46:29-32

Berkelmans R, Oliver JK (1999) Large-scale bleaching of corals on the Great Barrier Reef. Coral Reefs 18:55-60

Birkeland C (1977) The importance of rate of biomass accumulation in early successional stages of benthic communities to the survival of coral recruits. In: Taylor DL (ed) Proceedings of the 3rd International Coral Reef Symposium, Vol. 1. Rosenstiel School of Marine and Atmospheric Science, University of Miami, p 15-21

Birkeland C (1987) Nutrient availability as a major determinant of differences among coastal hard-substratum communities in different regions of the tropics. UNESCO Rep Mar Sci 46:45-96

Brown BE (1997) Coral bleaching: causes and consequences. Coral Reefs 16:S129-S138

Carpenter RC (1990) Mass mortality of Diadema antillarum. I. Long-term effects on sea urchin population-dynamics and coral reef algal communities. Mar Biol 104:67-77

Connell JH, Hughes TP, Wallace CC (1997) A 30-year study of coral abundance, recruitment, and disturbance at several scales in space and time. Ecol Monogr 67:461-488

Done TJ (1982) Patterns in the distribution of coral communities across the central Great Barrier Reef. Coral Reefs 1: 95-107

Done TJ, Potts DC (1992) Influences of habitat and natural disturbances on contributions of massive Porites corals to reef communities. Mar Biol 114:479-493

Fishelson L (1973) Ecological and biological phenomena influencing coral-species composition on the reef tables at Eilat (Gulf of Aqaba, Red Sea). Mar Biol 19:183-196

Glynn PW (1990) Coral mortality and disturbances to coral reefs in the Tropical Eastern Pacific. In: Glynn PW (ed) Global ecological consequences of the 1982-83 El Niñosouthern oscillation. Elsevier, Amsterdam, p 55-126

Glynn PW (1993) Coral reef bleaching: ecological perspectives. Coral Reefs 12:1-17

Harlin MM, Lindbergh JM (1977) Selection of substrata by seaweeds: optimal surface relief. Mar Biol 40:33-40
Hatcher BG (1984) A maritime accident provides evidence for alternate stable states in benthic communities on coral reefs. Coral Reefs 3:199-204

Heyward AJ, Negri AP (1999) Natural inducers of coral larval metamorphosis. Coral Reefs 18:273-279

Hixon MA, Brostoff WN (1996) Succession and herbivory: effects of differential fish grazing on Hawaiian coral-reef algae. Ecol Monogr 66:67-90

Hoegh-Guldberg O (1999) Climate change, coral bleaching and the future of the world's coral reefs. Mar Freshw Res 50:839-866

Hopley D (1982) The geomorphology of the Great Barrier Reef: quaternary development of coral reefs. John Wiley Interscience, New York

Hughes TP (1996) Demographic approaches to community dynamics: a coral reef example. Ecology 77:2256-2260

Hughes TP, Szmant AM, Steneck RS, Carpenter RC, Miller S (1999) Algal blooms on coral reefs: what are the causes? Limnol Oceanogr 44:1583-1586

Jompa J, McCook LJ (1998) Seaweeds save the reefs?!: Sargassum canopy decreases coral bleaching on inshore reefs. Reef Res 8:5

Jompa J, McCook LJ (2002) Effects of competition and herbivory on interactions between a hard coral and a brown alga. J Exp Mar Biol Ecol (in press)

Klumpp DW, McKinnon AD (1992) Community structure, biomass and productivity of epilithic algal communities on the Great Barrier Reef: dynamics at different spatial scales. Mar Ecol Prog Ser 86:77-89

Lang JC, Chornesky EA (1990) Competition between scleractinian reef corals - a review of mechanisms and effects. In: Dubinsky Z (ed) Ecosystems of the world, Vol 25. Coral reefs. Elsevier, Amsterdam, p 209-252

Lapointe BE (1999) Simultaneous top-down and bottom-up forces control macroalgal blooms on coral reefs (Reply to the comment by Hughes et al.). Limnol Oceanogr 44: 1586-1592

Le Bris S, Le Campion-Alsumard T, Romano JC (1998) Characteristics of epilithic and endolithic algal turf exposed to different levels of bioerosion in French Polynesian coral reefs. Oceanol Acta 21:695-708

Le Campion-Alsumard T, Golubic S, Hutchings PA (1995) Microbial endoliths in skeletons of live and dead corals: Porites lobata (Moorea, French Polynesia). Mar Ecol Prog Ser 117:149-157

Littler MM, Littler DS (1997) Disease-induced mass mortality of crustose coralline algae on coral reefs provides rationale for the conservation of herbivorous fish stocks. In: Lessios HA, Macintyre IG (eds) Proceedings of the 8th International Coral Reef Symposium, Vol. 1. Smithsonian Tropical Research Institute, Panama, p 719-724

Lopez-Rodriguez C, Perez-Cirera JL (1998) The effects of different environmental conditions on colonization and succession in the Fucus vesiculosus community on the Galician coasts (Northwestern Iberian Peninsula). Bot Mar 41: 581-591

Marshall PA, Baird AH (2000) Bleaching of corals on the Great Barrier Reef: differential susceptibilities among taxa. Coral Reefs 19:155-163

McClanahan TR (1997) Primary succession of coral-reef algae: differing patterns on fished versus unfished reefs. J Exp Mar Biol Ecol 218:77-102

McClanahan TR, Muthiga NA (1998) An ecological shift in a remote coral atoll of Belize over 25 years. Environ Conserv 25:122-130

McClanahan TR, Muthiga NA, Mangi S (2001) Coral and algal changes after the 1998 coral bleaching: interaction 
with reef management and herbivores on Kenyan reefs. Coral Reefs 19:380-391

McCook LJ (1999) Macroalgae, nutrients and phase shifts on coral reefs: scientific issues and management consequences for the Great Barrier Reef. Coral Reefs 18:357-367

McCook LJ (2001) Competition between corals and algal turfs along a gradient of terrestrial influence in the nearshore central Great Barrier Reef. Coral Reefs 19:419-425

McCook LJ, Chapman ARO (1993) Community succession following massive ice-scour on a rocky intertidal shore: recruitment, competition and predation during early, primary succession. Mar Biol 115:565-575

McCook LJ, Chapman ARO (1997) Patterns and variations in natural succession following massive ice-scour of a rocky intertidal seashore. J Exp Mar Biol Ecol 214:121-147

McCook LJ, Jompa J, Diaz-Pulido G (2001a) Competition between corals and algae on coral reefs: a review of evidence and mechanisms. Coral Reefs 19:400-417

McCook LJ, Wolanski E, Spagnol S (2001b) Modelling and visualizing interactions between natural disturbances and eutrophication as causes of coral reef degradation. In: Wolanski E (ed) Oceanographic processes of coral reefs: physical and biological links in the Great Barrier Reef. CRC Press, Boca Raton, p 113-125

Meesters EH, Bak RPM (1993) Effects of coral bleaching on tissue regeneration potential and colony survival. Mar Ecol Prog Ser 96:189-198

Price IR (1975) The development of algae on the skeletons of reef-building corals. In: Anonymous (ed) Crown-of-thorns starfish seminar proceedings. Australian Government Publishing Service, Canberra, p 181-191

Price IR, Scott FJ (1992) The turf algal flora of the Great Barrier Reef. Part I. Rhodophyta. James Cook University of North Queensland, Townsville

Editorial responsibility: Charles Birkeland (Contributing Editor), Honolulu, Hawaii, USA
Russ GR, McCook LJ (1999) Potential effects of a cyclone on benthic algal production and yield to grazers on coral reefs across the central Great Barrier Reef. J Exp Mar Biol Ecol 235:237-254

Scott FJ, Russ GR (1987) Effects of grazing on species composition of the epilithic algal community on coral reefs of the central Great Barrier Reef. Mar Ecol Prog Ser 39:293-304

Steneck RS, Dethier MN (1994) A functional group approach to the structure of algal-dominated communities. Oikos 69:476-498

Sweatman H, Bass D, Cheal A, Coleman G, Miller I, Ninio R, Osborne K, Oxley W, Ryan D, Thompson A, Tomkins P (1998) Long-term monitoring of the Great Barrier Reef: status report. Australian Institute of Marine Science, Cape Cleveland, Townsville

Szmant AM, Gassman NJ (1990) The effects of prolonged 'bleaching' on the tissue biomass and reproduction of the reef coral Montastrea annularis. Coral Reefs 8: 217-224

ter Braack CJF, Šmilauer P (1998) CANOCO reference manual and user's guide to Canoco for Windows. Software for Canonical Community Ordination (Version 4). Centre for Biometry Wageningen, Wageningen

Underwood AJ (1986) The analysis of competition by field experiments. In: Kikkawa J, Anderson DJ (eds) Community ecology: pattern and process. Blackwell, Oxford, p 240-268

van Woesik R (1998) Lesion healing on massive Porites spp. corals. Mar Ecol Prog Ser 164:213-220

Wellington GM, Victor BC (1985) El Niño mass coral mortality: a test of resource limitation in a coral reef damselfish population. Oecologia 68:15-19

Wilkinson CR (2000) Status of coral reefs of the world: 2000. Australian Institute of Marine Science, Townsville

Submitted: May 7, 2001; Accepted: October 10, 2001

Proofs received from author(s): April 8, 2002 